\title{
Peertechz
}

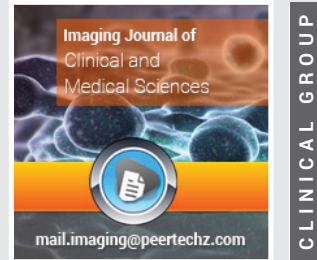

IMAGING JOURNAL OF

Clinical and Medical Sciences

Clinical Image

\section{Exclusive Image Gallery on Human Spinal Cord Regeneration}

\section{Giselher Schalow*}

MD, PhD, Untere Kirchmatte 6, CH-6207 Nottwil, Switzerland

\section{Received: 22 May, 2019}

Accepted: 15 June, 2019

Published: 16 June, 2019

*Corresponding author: Giselher Schalow, Professor, Untere Kirchmatte 6, CH-6207 Nottwil, Switzerland, E-mail: g_schalow@hotmail.com

https://www.peertechz.com
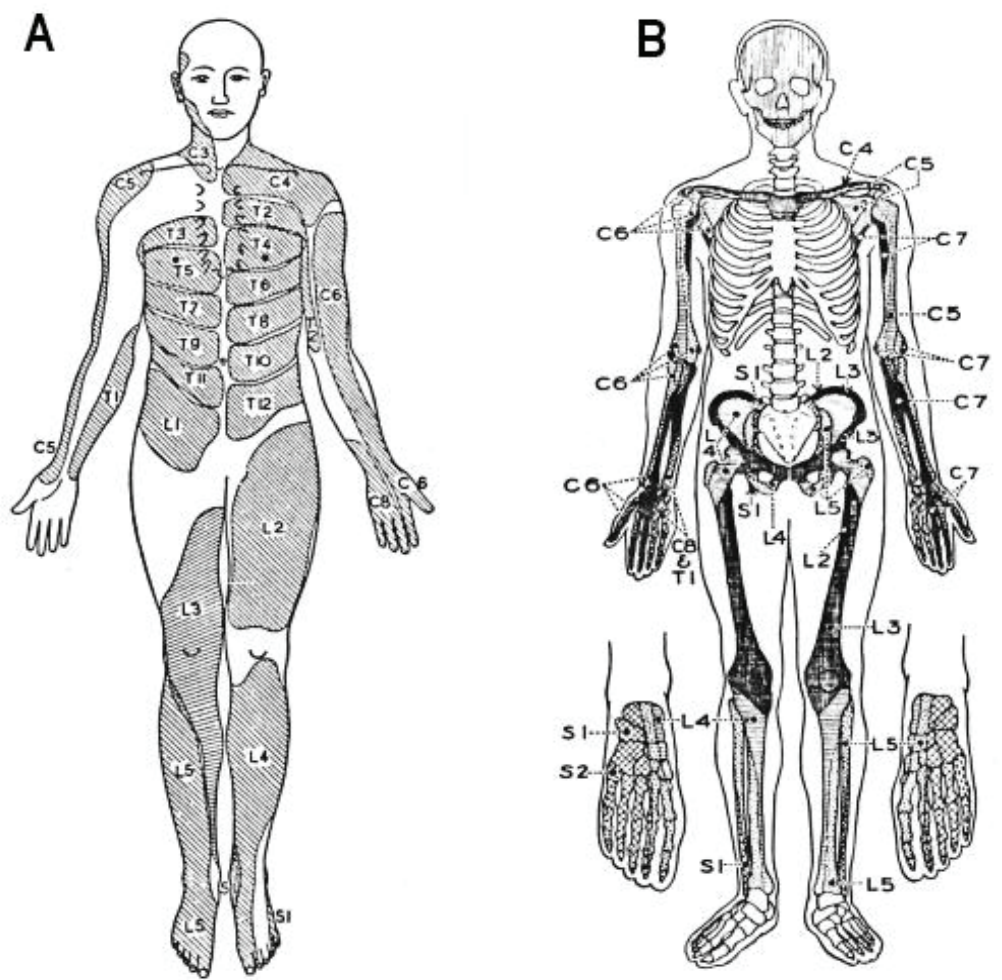

Copyright: (c) 2019 Schalow G. This is an open-access article distributed under the terms of the Creative Commons Attribution License, which permits unrestricted use, distribution, and reproduction in any medium, provided the original author and source are credited. 